\title{
Bishops of the Habit in Castile, I62I-I665: A Prosopographical Approach
}

\author{
by HELEN RAWLINGS
}

The seventeenth-century Spanish Church stood out among other Catholic countries of western Europe on account of the high percentage of members of the religious orders - especially Dominicans - recruited as bishops. While their authority as preachers and theologians, schooled in the post-Tridentine tradition, made them eminently suitable candidates for office, they had none of the secular experience normally required of an episcopate that worked in close alliance with the state. The political and fiscal pressures placed on this alliance under Philip IV prompted an unprecedented crisis of recruitment to the Spanish church hierarchy, of which the religious orders became the direct beneficiaries.

$\mathrm{I}$ $\mathrm{n}$ early sixteenth-century Spain, ahead of the historic schism in the western Church, the religious orders addressed themselves to the urgent task of raising the level of professional and theological expertise that lay within their ranks. They did so in the face of widespread accusations of neglect, ignorance, false piety and corruption, as expounded in Erasmus' Praise of folly (1509). As a result of their initiatives, the mendicant orders in particular emerged as some of the most distinguished preachers, teachers and religious advisors in the late sixteenth- and early seventeenth-century Spanish Church, arguably surpassing the calibre to be found within the body of the secular clergy. The reform of the orders was matched by a significant

AHN, consejos=Archivo Histórico Nacional, Madrid, consejos suprimidos; ASV, $\mathrm{PC}=$ Archivio Segreto Vaticano, Rome, processus consistoriales; DHEE=Q. Alden, T Marin and J. Vives (eds), Diccionario de historia eclesiástica de España, Madrid i972-5

This article is based upon a paper given at a conference on 'The religious orders at the court of Philip IV', held at the Institute of Romance Studies, University of London. Research in the Vatican Archives was supported by a British Academy Small Research Grant. I wish to thank Professor Terence O'Reilly and Dr Anthony Wright for their comments. 
expansion in their number. There were a total of $\mathrm{I}, 326$ religious communities (84 I male and 485 female) in the kingdom of Castile at the accession of Philip III in I598. By the beginning of the reign of Philip IV, just over twenty years later, there were reported to be 2,I4I in Spain as a whole. This figure may have risen to 3,000 by I700. The most dramatic growth was registered in the size of the mendicant orders, notably the Franciscans and the Dominicans, as well as the Observant Augustinians, Discalced Carmelites, Mercedarians and Trinitarians. Male mendicant order membership rose from I2,000 in Castile in I59 I to an estimated 34,000 throughout Spain in I623. By contrast, the size of the male monastic orders (including the Benedictines, Carthusians, Cistercians and Jeronimites) largely remained unchanged over this same period. ${ }^{1}$

Both Philip III and Philip IV were renowned patrons of the orders. Both monarchs actively encouraged the founding of new and reformed religious communities in order to meet the devotional needs of lay society on the one hand and to sanctify their own positions on the other. They did so despite a growing public outcry, voiced by contemporary observers (some of whom were churchmen), at the excessive number of regulars. The orders, charged with saving the soul of the nation, clearly absorbed many men and women who were seeking a refuge from the rigours of secular existence in early seventeenth-century Spain rather than pursuing a genuine religious vocation. In I62 I the Funta de Reformación, an executive branch of the Council of Castile, reported to Philip IV that 'the majority of regular clergy currently in these kingdoms follow this path as a means of getting enough food to eat rather than out of Christian duty or devotion'. ${ }^{2}$ Numerous attempts made by the Cortes of Castile to link its concession of a regular fiscal subsidy to the crown (known as the servicio) to a restraint being placed on the licensing of new monasteries failed to prevent their continued expansion. ${ }^{3}$

Protected by the crown, the orders established an important power base in society, legitimised through further royal concessions. Madrid, re-established as the Spanish capital in I6o6, experienced a veritable explosion in the size of its religious communities during the first half of the seventeenth century. At the beginning of the reign of Philip III there were eleven monasteries and seven convents in Madrid, housing just over I,ooo friars and nuns. By the accession of Philip IV in I62I, the total number of religious establishments in

${ }^{1}$ Felipe Ruiz Martín, 'Demografía eclesiástica', DHEE ii. 682-733; Annie MoliniéBertrand, 'Le Clergé dans le royaume de Castille à la fin du xvi siècle', Revue d'histoire economique et sociale li (1978), 5-53; Antonio Domínguez Ortiz, Las clases privilegiadas en el antiguo régimen, Madrid 1979, 274-5; Gil González Dávila, Teatro de las grandezas de la villa de Madrid, Madrid ı623, facsimile edn, Madrid ı986, 234-99.

${ }^{2}$ Archivo Histórico Español, ed. A. Gonález Palencia, V: La Junta de Reformación, I6I8-25, Valladolid i932, document 42, pp. 256-8.

${ }^{3}$ Actas de las Cortes de Castilla, xxvi (Cortes of Madrid, I607), 280-I; liv (Cortes of Madrid, I633), 242 . 
the city had risen to thirty-one (nine of them Franciscan) and their membership had more than doubled to just over $2,500{ }^{4}$

It was at the royal court in Madrid, the centre stage of Philip IV's monarchy, where pomp and ceremony provided the backdrop for diplomacy, political intrigue and the exercise of royal patronage, that senior members of the religious orders came to the attention of the king and his first minister, the count-duke of Olivares. ${ }^{5}$ There may have been as many as Ioo religious attached to the royal household including the senior royal chaplain (an office traditionally held by the archbishop of Santiago), responsible for religious ceremony at court and the management of the royal chapel; the royal confessor (a position reserved for a leading Dominican); the grand almoner, in charge of distributing alms in accordance with royal wishes; ten royal preachers drawn from different orders, as well as numerous lesser chaplains and confessors to other members of the royal household. On special occasions the provincials and generals of the major orders might also be in attendance, underlying the importance of their relationship with the monarchy. The wider presence of the religious orders in society and at court paved the way for their preferment to the hierarchy of the Spanish Church. It is the purpose of this article to examine the reasons for the rise in prominence of regulars to the office of bishop within the Castilian branch of the Spanish Church (the largest of its two divisions) under Philip IV (I62 I-65), the Habsburg reign that witnessed the greatest number of bishoprics being conferred on members of the orders, and to assess the phenomenon in the context of the leadership of the Castilian Church as a whole during this period. ${ }^{6}$

\section{II}

By the middle of Philip II's reign, as the crown strengthened its control over ecclesiastical patronage and directed the implementation of episcopal reform

${ }^{4}$ José Antonio Álvarez y Baena, Compendio histórico de las grandezas de la coronada villa de Madrid, Madrid I786, 98-I77; María F. Carbajo Isla, La población de la villa de Madrid, Madrid I987, ch. vi; Alfredo Alvar Ezquerra, El nacimiento de una capital europea: Madrid entre I5I6 y I606, Madrid I989, ch i.

5 J. H. Elliott, 'The court of the Spanish Habsburgs : a peculiar institution?', in his Spain and its world, I500-I700, Yale I989, I42-6I, and 'Philip IV of Spain: a prisoner of ceremony', in A. G. Dickens (ed.), The courts of Europe, London 1977, I79-80.

6 The statistical and biographical data used in the compilation of this article has been drawn from the episcopal nomination records for the reign of Philip IV, found in $\mathrm{AHN}$, consejos, legajos I522I-93 (I62I-65); ASV, PC, vols I7-I8, 22, 32-3, 38, 40, 48, 50, 57, 6o (I62 I-63). Additional supportive evidence has been taken from P. B. Gams, Series episcoporum ecclesiae catholicae, Leipzig I93I; G. V. Gulik and C. Eubel, Hierarchia catholica medii aevi, iii-v, Munich 1935-40; Gil González Dávila, Teatro eclesiástico de las iglesias metropolitanas y catedrales de los reynos de las dos Castillas, Madrid I645-1700. 
Table I. Castilian episcopal sees held by religious orders, ${ }_{5}{ }^{16} 6-1700$

\begin{tabular}{|c|c|c|c|c|c|}
\hline Order & Charles V & Philip II & Philip III & Philip IV & Charles II \\
\hline \multicolumn{6}{|l|}{ OSA } \\
\hline Augustinians (I I) & I & I & I & 4 & 4 \\
\hline OSB & & & & & \\
\hline $\begin{array}{l}\text { Benedictines (I4) } \\
\text { Ocarm }\end{array}$ & 2 & - & 2 & 6 & 4 \\
\hline $\begin{array}{l}\text { Carmelites (I) } \\
\text { Ocist }\end{array}$ & - & - & - & - & I \\
\hline Cistercians (4) & - & - & - & 2 & 2 \\
\hline $\begin{array}{l}\text { OSD } \\
\text { Dominicans (39) } \\
\text { OSF }\end{array}$ & 8 & 6 & 5 & $\mathrm{I} 2$ & 8 \\
\hline Franciscans (36) & 4 & 6 & 7 & Io & 9 \\
\hline $\begin{array}{l}\text { OSJ } \\
\text { Jeronimites (9) } \\
\text { OMerc }\end{array}$ & 2 & I & - & 5 & I \\
\hline $\begin{array}{l}\text { Mercedarians (6) } \\
\text { OssT }\end{array}$ & - & - & - & 2 & 4 \\
\hline Trinitarians (3) & I & - & I & - & I \\
\hline Total per reign & I8 & I4 & I6 & $4 \mathrm{I}$ & 34 \\
\hline $\begin{array}{l}\% \text { all bishops } \\
\text { appointed per reign }\end{array}$ & $\begin{array}{c}\mathrm{I} 8 \\
\text { (I00) }\end{array}$ & $\begin{array}{c}\mathrm{I} 2 \\
(\mathrm{II} 5)\end{array}$ & $\begin{array}{c}24 \\
(66)\end{array}$ & $\begin{array}{c}27 \\
(\mathrm{I} 53)\end{array}$ & $\begin{array}{l}36 \\
(94)\end{array}$ \\
\hline
\end{tabular}

as decreed at the third session of the Council of Trent (I562-3), a typical profile of a Castilian bishop had begun to emerge. ${ }^{7} \mathrm{He}$ was a member of the secular rather than the regular clergy, of middle noble family origins, university educated in theology and/or canon law, possibly to doctoral level, with a background of experience in a cathedral chapter or within the secular administration, most notably as an inquisitor. Members of the religious orders were rarely first choice candidates. Those friars who did obtain bishoprics under Philip II (I2 per cent of appointees in Castile) tended to be confined to geographical outposts of the peninsula in need of theological guidance, such as Galicia in the north-west, Aragón in the north-east and the Canary Islands off the north African coast, or otherwise sent to the New World. ${ }^{8}$ Regular clergy were not prepared or trained for episcopal office in

7 Helen Rawlings, Church, religion and society in early modern Spain, Palgrave 2002, 58-67, and 'The secularisation of Castilian episcopal office under the Habsburgs, c. I5 $16-{ }^{1}$-1700', this Journal xxxviii (1987), 53-79 at pp. 68-9.

${ }^{8}$ Ignacio Fernández Terricabras, 'Por una geografia del patronazgo real: teólogos y juristas en las presentaciones episcopales de Felipe II', in Enrique Martínez Ruiz and Vicente Suárez Grimón (eds), Iglesia y sociedad en el antiguo regimen: III reunión científica de la Asociación Española de Historia Moderna, Las Palmas I994, 60I-9. 
the same way as secular clergy were. In the case of mendicants, their experience (including their educational background) was acquired within the professional and vocational structure of their order rather than within the wider Church and community. The Franciscans, for example, bound by vows of humility and poverty, did not take university degrees. ${ }^{9}$ According to canon law, friars were not intended to be bishops, for in this capacity they stepped outside the boundaries of their rule (based on poverty) and became involved in secular affairs. A friar effectively renounced his vows once he became a bishop. This opinion was endorsed by members of the Cámara de Castilla (a subcommittee of the Council of Castile with specific responsibility for patronage) in the I570s and 1580 s which advised Philip II on nominations to bishoprics. In his review of a list of candidates for the vacant see of Oviedo in October 1584 , Mateo Vázquez de Leca, private secretary to the king and camarista, suggested that friars should become bishops 'on as few occasions as possible' ${ }^{\mathbf{1 0}}$ The trend was set to change dramatically under the later Habsburgs.

The number of members of the religious orders appointed as Castilian bishops more than doubled during the course of the first half of the seventeenth century: from I2 per cent of appointees under Philip II, to 24 per cent under Philip III, 27 per cent under Philip IV and 36 per cent under Charles II (see Table I). The Church in the neighbouring crown of Aragón also witnessed a similar phenomenon. ${ }^{11}$ The appointment of bishops of the habit represented an important new departure in preferment practice to emerge under the later Philips and their favourites. Members of the orders now became major rather than minor contenders for Castilian bishoprics. In I626 Philip Iv issued a brief to the Cámara urging them not to exclude members of the orders from consultas, 'for it is not an office from which personal profit is to be made and should not be regarded as incompatible with their vows'. ${ }^{12}$ Of the 153 men appointed to serve as bishops in Castile

9 ASV, PG, vol. I8, fo. 469r. (Juan de Arauz OSF, nominated for Guadix, i624: 'no es graduado porque en su orden no seleccionan grados por las universidades por la humildad y costumbre que en ella se conserva' / 'he is not a graduate because members of his order select on the basis of humility rather than university degree'); vol. 22, fo. 6or. (Juan Venido osf, nominated for Orense, i626: 'porque en la dicha religión no se usa ni acostumbra por la humildad, recibir ni dar los dichos grados'/ 'for in this order it is not customary to give degrees'); vol. 40, fo. 39Ir. (Francisco Guerra OSF, nominated for Cádiz, i642: 'en dicha religión de San Francisco no hay grados de doctor, ni maestro, no otros'/ 'in the said order of Saint Francis there are no doctoral or masters, or equivalent degrees').

${ }^{10}$ Instituto Valencia Don Juan, Madrid, envío 9o, fo. 88, 'Personas para el obispado de Oviedo, 3 Sep 1584 '/ 'Candidates for the bishopric of Oviedo, 3 Sept I584'.

11 M. Barrio Gozalo, 'Perfil socio-económico de una élite de poder, VIII: Los obispos del reino de Aragón (I536-I834)', Anthológica Annua xliii (I996), I07-2 I2.

$12 \mathrm{AHN}$, consejos, libro 2726, fos I29-30 (decreto del 8 de noviembre de 1626 sobre proponer religiosos para obispados), cited by Antonio Domínguez Ortiz, La sociedad española del siglo xvii, II: El estamento eclesiástico, Granada I992, appendix xxvi, 266. 
Table 2. Castilian bishoprics held by mendicant and monastic orders under Philip IV

\begin{tabular}{lc}
\hline \hline $\begin{array}{l}\text { Total bishoprics held by } \\
\text { mendicant orders (43) }\end{array}$ & $\begin{array}{l}\text { Total bishoprics held } \\
\text { by monastic orders (22) }\end{array}$ \\
\hline OSD (24) & OSJ (9) \\
OSF (I2) & OSB (IO) \\
OSA (5) & Ocist (3) \\
OMerc (2) & \\
\hline \hline
\end{tabular}

under Philip IV, forty-one (27 per cent) were members of the religious orders who between them - taking account of transfers and promotions - held sixtyfive (24 per cent) of the 266 offices dispensed. Almost twice as many Castilian bishoprics were held by mendicant as by monastic clergy. In contemporary France, over a period equivalent to the reigns of Philip III and Philip IV (I589-166r), only I2 per cent of bishops were drawn from the orders, balanced between old (monastic) and new (mendicant) branches. ${ }^{13}$

Thirty-five per cent of offices held by members of the orders were of low rental value and status within the Castilian Church (with annual incomes of less than 15,000 ducats in I630). Sees that fell into this category were predominantly located in remote areas of the peninsula, often in much need of pastoral guidance. The appointment of religious at this level was in keeping with their traditional role within the Church as pastors and preachers, qualities that accorded with the Tridentine model of a 'good bishop'. Thirty-five per cent were of middle rental value (with incomes of between I5,000 and 30,000 ducats) and 29 per cent of high rental value (with incomes of over 30 ,ooo ducats). ${ }^{14}$ The number of appointments made to religious within the middle and higher ranks of the episcopate was significant for this was where the administrative and political challenges of office were arguably the greatest - tasks for which members of the orders were generally considered unsuited. Regulars now had a one in three chance of preferment not just as religious but also as secular leaders of the Spanish Church, working in close alliance with the crown. Furthermore, the representation of the orders at the highest level of office witnessed a considerable increase on the previous reign when it stood at ig per cent.

\section{III}

Specific entry points to episcopal office for members of the orders that had emerged under Philip III became more regularly established under Philip IV.

${ }^{13}$ Joseph Bergin, The making of the French episcopate, I589-I66I, Yale I996, 265-8.

14 Figures for episcopal rents (c. I630) derived from AHN, consejos, legajos I 522 I- 36 . 
Table 3. Bishops of the habit per Castilian diocese under Philip IV

\begin{tabular}{|c|c|c|c|}
\hline $\begin{array}{l}\text { Bishopric and value } \\
\text { (low, middle, high) }\end{array}$ & $\begin{array}{l}\text { Total } \\
\text { appts }\end{array}$ & $\begin{array}{l}\text { To } \\
\text { orders }\end{array}$ & $\begin{array}{l}\text { Members of religious orders appointed to see } \\
\text { during reign (year of appointment in brackets) }\end{array}$ \\
\hline Almería (L) & II & 4 & OSD (I630); OSB (I637); OSB (I651); ocist (I659) \\
\hline Astorga (L) & 6 & I & osJ $(\mathrm{i} 654)$ \\
\hline Ávila $(\mathbf{M})$ & 9 & o & \\
\hline Badajoz (M) & 8 & 3 & OsB (I640); ocist (I645); oMerc (I662) \\
\hline Burgos $(\mathrm{H})$ & 7 & I & $\operatorname{OSD}(\mathrm{I} 630)$ \\
\hline Cádiz (L) & 7 & 5 & $\begin{array}{l}\text { OSB (I623); OSD (I633); OSF (I642); Ocist (I663); } \\
\text { OSF (I663) }\end{array}$ \\
\hline Calahorra (M) & 8 & 2 & osB (I657); OSB (I659) \\
\hline Canaries $(\mathrm{M})$ & 7 & 3 & OSD (I62I); OSF (I622); OSJ (I659) \\
\hline Cartagena $(\mathbf{M})$ & 7 & o & \\
\hline Ciudad Rodrigo (L) & 8 & I & OSA (I623) \\
\hline Córdoba $(\mathrm{H})$ & 7 & 2 & OSD (I633); OSD (I649) \\
\hline Coria $(\mathrm{M})$ & IO & 2 & OSF (I644); OSA (I659) \\
\hline Cuenca $(\mathrm{H})$ & 3 & o & \\
\hline Granada $(\mathrm{H})$ & 6 & o & \\
\hline Guadix (L) & 7 & 4 & OSF (I624); OSA (I648); OMerc (I652); OSA (I653) \\
\hline Jaén $(\mathrm{H})$ & 3 & $\mathrm{o}$ & \\
\hline León $(\mathrm{M})$ & 8 & 3 & OSJ (I624); OSD (I65o); OSJ (I665) \\
\hline Lugo (L) & II & 2 & OSJ (1643); OSD (1646) \\
\hline Málaga $(\mathrm{H})$ & 9 & 2 & OSF (I633); OSD (I664) \\
\hline Mondoñedo $(\mathrm{L})$ & 6 & I & OSD $(\mathrm{I} 648)$ \\
\hline Orense $(\mathrm{L})$ & 9 & 2 & OSF (I626); OSB (I653) \\
\hline Osma $(\mathrm{M})$ & 9 & 4 & OSD (I63o); OSJ (I66o); OSD (I66I); OSD (I664) \\
\hline Oviedo $(\mathrm{L})$ & 7 & 0 & \\
\hline Palencia (M) & 6 & o & \\
\hline Pamplona (M) & 8 & I & $\operatorname{OSD}(\mathrm{I} 625)$ \\
\hline Plasencia $(\mathrm{H})$ & 9 & 3 & OSB (I633); OSF (I656); OSD (I664) \\
\hline Salamanca (M) & IO & o & \\
\hline Santiago $(\mathrm{H})$ & 6 & 2 & OSA (I624); OSD (I627) \\
\hline Segovia $(\mathrm{H})$ & 9 & 4 & OSD (I622); OSD (I64I); OSD (I648); OSD (I656) \\
\hline Seville $(\mathrm{H})$ & 8 & 3 & OSD (I649); OSD (I652); OSF (I658) \\
\hline Sigüenza $(\mathrm{H})$ & 7 & $\begin{array}{l}3 \\
2\end{array}$ & OSF (I622); OSD (I645) \\
\hline Toledo $(\mathrm{H})$ & 2 & $\mathrm{o}$ & \\
\hline Tuy (L) & II & 3 & OSJ (I62I); OSD (I622); OSF (I659) \\
\hline Valladolid (M) & 5 & 2 & OSJ (I633); OSF (I647) \\
\hline Zamora $(\mathrm{M})$ & $\mathrm{I} 2$ & 3 & OSJ (I622); OSB (I624); OSB (I659) \\
\hline Totals & 266 & 65 & \\
\hline
\end{tabular}

Those religious who had previously served as royal preachers or confessors, as provincials and generals of their orders, as university professors and as theological advisors (calificadores) to the inquisition all became major contenders for promotion to the Castilian episcopal bench. The Dominicans were the most successful order to infiltrate the Spanish church hierarchy under Philip IV, holding a total of twenty-four offices, fourteen of which were of high 
status. (This compares with a total of six offices, of which one was at high status, under Philip III.) Their professional rise to positions of seniority, established via a number of key power bases, set a precedent for other orders to follow and to challenge.

There were discernible reasons for the rise of the Dominicans to power within the Church. The order had undergone a programme of root and branch reform under the Catholic Kings, taking a leading role in the Spanish mendicant reform movement. The sixteenth century was the siglo de oro of the Spanish Order of Preachers. It was the second largest male religious order in Castile (after the Franciscans), established in virtually every town, with a membership of 2,500 recorded in the I59I census. The order produced some of the most distinguished theologians and preachers of the early modern period, whose ideology and theological discipline (based upon the teachings of St Thomas Aquinas) was to exercise a fundamental influence on the shape of Spanish orthodoxy in the early modern period. Thirty Dominicans took part in the Council of Trent (I545-63), where, despite theological differences, they adopted a conservative approach to reform. They included the brothers Pedro and Domingo de Soto, Bartolomé de Carranza y Miranda (the future archbishop of Toledo), Melchor Cano (his academic rival), Diego de Chaves (confessor to Philip II) and Juan Gallo, each of whom held the distinguished professorial chair of Prima de Teología at Salamanca. The University of Salamanca was one of the major centres of scholarship in late sixteenth- and early seventeenth-century Castile. It was to provide an important academic forum for the theological expertise nurtured from within the Dominican monastery-academy of San Esteban in the city. Between I490 and I645, the School of Salamanca produced a total of thirty-four bishops and archbishops, two inquisitors-general, four royal preachers and more than thirty provincials, writers and professors, as well as numerous overseas missionaries. ${ }^{15}$

In I606 a new Salamanca chair in Thomist Theology was established exclusively for a leading Dominican from San Esteban by Philip III and the duke of Lerma (who had become a patron and protector of the order in Castile from i6o3). At the same time the order relinquished its right to the original Prima de Teología, over which its members had held a monopoly for almost 200 years. Two further professorial chairs in theology were created specifically for San Estebanistas under the patronage of the king and duke in succeeding years: the Cátedra de Vísperas at Salamanca in I6o8 and the Cátedra de Santo Tomás at Valladolid in i6ri. The holders of these chairs were automatic contenders for Castilian episcopal sees. ${ }^{16}$

15 Gil González Dávila, Teatro eclesiástico, iii, Madrid ı65o, iglesia de Salamanca, fos 206-15.

16 Holders of Prima chair at Salamanca: Diego Herrera (I6o4-2I), bp Canaries (I62 I-2), bp Tuy (I622-30), abp Tarazona (I630-I); Francisco de Araujo (I62I-48), bp Segovia (I648-56); Pedro de Godoy (ı652-64), bp Osma (ı664-72), bp Sigüenza (ı672-7): DHEE ii. 766-72. 
The Dominicans were highly influential figures within the Holy Office, which they had been instrumental in establishing in Castile in 1478. As professional theological advisors (calificadores) they had an overriding influence in doctrinal issues and, arguably, over the whole ideological direction of postTridentine Spain. In I6r4 a supernumerary councillorship of inquisition (previously held by a Franciscan) was permanently reserved for a member of the Dominican order, confirming their privileged position within the Catholic state. The first man to hold the office was Luis de Aliaga, the controversial confessor to Philip III (I608-2I) who, in conjunction with the Franciscan royal chaplain Juan de Santamaría, led a factional struggle between i6ı 8 and I6 19 aimed at removing the duke of Lerma from court. ${ }^{17}$ The Dominicans had held a monopoly over the royal confessorship since I2I8, a position which gave the holder intimate access to the royal conscience, making him the most trusted personal advisor to the king next to the favourite. It was traditional for the royal confessor to be consulted in choosing candidates for episcopal preferment and for his opinion to be sought on major issues of Church and State.

The Dominican friar, Antonio de Sotomayor, who was royal confessor from I62 I to I643 and inquisitor-general between I632 and I643, exercised a major influence in the distribution of royal patronage during the first half of the reign of Philip IV. The royal favourite, the count-duke of Olivares, who may have assisted Sotomayor's rise to office, was quite content to allow him to take the initiative in appointment-making procedures, apparently without consultation. From i635 the Cámara de Castilla made formal announcements of vacant bishoprics as they arose but, in contrast to the pattern established under Philip II and Philip III, the selection process leading to the nomination of the preferred candidate was undocumented. (A similar reduction in the consultative process also affected the competition for inquisitorial office.) In I638 Olivares remarked that 'ecclesiastical business is managed by His Majesty's confessor, without me knowing anything more about one or the other than is known by the secretaries and officials of the Protonotorio's office, and a good deal less'. ${ }^{18}$ Sotomayor was renowned for his exercise of favouritism in the distribution of offices, by-passing councillors and camaristas. Ten Dominicans rose to Castilian bishoprics during his tenure as royal confessor. Two of his nephews were elevated through the episcopal ranks: Diego de Zúñiga y Sotomayor (from Orense to Zamora in 1634) and Fernando Andrade de Sotomayor (from Burgos to Sigüenza in i64o and from Sigüenza to the family see of Santiago in I645). Sotomayor's forced retirement from office in June $\mathrm{i} 643$, at the request of the papacy, was an acknowledgement, albeit veiled, that he had exceeded his powers and perhaps that the

${ }^{17} \mathrm{~J}$. H. Elliott, The Count-Duke Olivares: the statesman in an age of decline, Yale 1986, 95, I02; Patrick Williams, 'Lerma, I6ı8: dismissal or retirement?', European History Quarterly xiii (I989), $320,324^{-5}$.

18 Elliott, The Count-Duke Olivares, 533. 
Dominicans' heavy infiltration into inquisitorial and episcopal office had reached its peak. ${ }^{19}$

Over the course of Philip IV's reign the Dominicans were to find their role as royal advisors and confidants gradually undermined by the rise of new orders with their own distinctive theological outlooks. Their refusal to support the cult of the Immaculate Conception of the Virgin Mary (which implied that Mary had been conceived free from sin) set them apart from other orders, notably the Franciscans and the Jesuits, both fervent Immaculists, who elicited the support of Philip III and Philip IV in seeking to have devotion to the Virgin Immaculate enshrined formally in Catholic doctrine. In I624 the Dominican Íñigo de Brizuela was obliged to renounce the bishopric of Segovia since it was a requirement of all those who held office within its church to support the doctrine. ${ }^{20}$ Pictorial representations of the Immaculate Conception by Spanish artists such as Velázquez, Murillo and Zurbarán, played an important role in the propaganda campaign to spread belief in the doctrine and raise it to the status of a dogma of the Catholic Church. The cult of the Immaculate Conception became a public crusade with the monarchy firmly identifying itself with the Virgin as its protectress in its traditional role as defender of the Spanish nation and its faith. Three special juntas of theologians were convened by Philip III in I6I6, I6I7 and I6I9 to discuss the matter and emissaries were sent to Rome to petition for papal recognition of the dogma, but without a conclusive outcome. The first emissary was Plácido Pacheco de Tosantos (OSB) in I6r6, later bishop of Guadix (I620-4) and Zamora (I624). The third emissary, Antonio de Trejo y Paniagua (OSF), was nominated to the bishopric of Cartagena in I6 6 8 prior to his departure for Rome in the following year, thus elevating his status as ambassador to the Holy See. Agustín Antolínez's (OSA) endorsement of the cult through his membership of the second junta (1617) brought him to the attention of the crown. He soon gained the confidence of the new king and rose to the bishopric of Ciudad Rodrigo in $1623 .{ }^{21}$ Membership of these juntas thus came to reflect the balance of power between the religious orders and their relationship with the monarch. ${ }^{22}$ The Dominicans were significantly

19 Memorial histórico español, xvii, Madrid I863, Cartas de algunos padres de la Compañía de Jesús (I634-48), entries for 3 Mar., 9 June I643.

${ }^{20}$ Gil González Dávila, Teatro eclesiástico, i, Madrid ı645, iglesia de Segovia, fos 590-3.

${ }^{21}$ ASV, PC, vol. I7, Ciudad Rodrigo (I623), referred to as a church dedicated to the Virgin.

${ }^{22}$ Suzanne L. Stratton, The immaculate conception in Spanish art, Cambridge I994, 73-5, 78-87, 98-Io4; R. A. Stradling, Philip IV and the government of Spain, I62I-I665, Cambridge I988, 344-7; A. D. Wright, Catholicism and Spanish society under the reign of Philip II, I55I-I598 and Philip III, I598-I62I, Lewiston, NY-Lampeter I99I, I30-2. 
excluded from the fourth (I643) and fifth (1652-65) juntas convened by Philip IV. Four of the theologians who served on the i $652-65$ committee were rewarded with bishoprics in acknowledgement of their service to the crown: Francisco Guerra (OSF), bishop of Plasencia (I656-8), Francisco Gamboa (OsA), bishop of Coria (1659-63), Alfonso Pérez (ocist ), bishop of Almería (I659-63) and Bernardo de Ontiveros (OSB), bishop of Calahorra (I659-62). ${ }^{23}$ By the end of the reign, after almost half a century of petitioning by the Spanish crown, the papacy agreed to allow the feast of the Immaculate Conception to be celebrated in Spain but it would not be enshrined in Catholic doctrine until I 854 .

From the i64os the Dominicans also found their privileged position within the higher echelons of academic life and the Holy Office gradually being eroded. The second half of the century saw the creation of multiple 'rival' chairs in theology reserved for different religious orders (including the Jesuits, the Benedictines and the Franciscans) at Salamanca, Alcalá de Henares and Valladolid, each representing different schools of theological thought. This marked the beginning of the decline of those university faculties dedicated to the teaching of theology in Spain and of the Dominicans' pre-eminence within them. The Dominicans were also finding their authority undermined on the council of inquisition. From the I62os the Jesuits began to infiltrate the office of calificador and within two decades outnumbered fellow Dominican members. ${ }^{24}$

They also took up the office of councillor. The first Jesuit to hold a councillorship of the inquisition (I63I) was Hernando Chirinos de Salazar, confessor to the count-duke of Olivares, who sat on various juntas, including that set up to address grievances against Rome on matters of ecclesiastical finance and discipline. Two years earlier Olivares, who described Salazar as 'the cleric in Spain to whom I owe most and whom I love most', had attempted to get his confessor nominated for the bishopric of Málaga but the papal dispensation required for a member of the Society of Jesus was not granted. ${ }^{25}$ The favouring of different orders at court exacerbated rivalries between them. In I6 34 Philip IV instructed the inquisitor-general to intervene in public disputes between them but they responded with a counter-attack. In the spring of 1637 two royal preachers - a Jesuit and a Capuchin friar - were expelled from court for attacking the government's economic policy in their sermons. ${ }^{26}$

${ }^{23}$ Juan Meseguer Fernández, 'La real junta de la Inmaculada Concepción (I6ı6-ı8ı7) 20)', Archivo Iberoamericano xv (1955), 663-7I. Alonso Pérez (ocist), nominated for Almería in I659, is referred to as 'uno de los de la junta de la inmaculada concepción de nra. Señora' / 'a member of the Immaculate Conception committee': ASV, PC, vol. 57, fo. 455r.

${ }^{24}$ José Martínez Millán, 'El consejo de la inquisición: (I483-170o), Hispania Sacra xxxvi (I984), 26. ${ }^{25}$ Elliott, The Count-Duke Olivares, I4I, 427.

26 Antonio Rodríguez Villa, La corte y monarquía de España en los años 1636 y ${ }_{1} 637$, Madrid I886, I27-31, entries for I8, 25 Apr. I637. 
Table 4. Dominicans and Jesuits as calificadores of the council of the inquisition

\begin{tabular}{lccccc}
\hline \hline Year & $\mathrm{I} 584-\mathrm{I} 600$ & $\mathrm{I} 600-\mathrm{IO}$ & $\mathrm{I} 6 \mathrm{II}-20$ & $\mathrm{I} 62 \mathrm{I}-30$ & $\mathrm{I} 63 \mathrm{I}-40$ \\
\hline Dominicans & 5 & 8 & 6 & 22 & I0 \\
Jesuits & 2 & 2 & - & I8 & 26 \\
\hline \hline
\end{tabular}

The second half of the reign of Philip IV witnessed a number of tensions within the higher ranks of the Church, partly motivated by the increased fiscal demands being placed upon the clerical estate by the crown to support its heavy military commitments in Europe and off-set falling state revenues, most notably those deriving from American silver. The period in question was characterised by a particularly high rate of episcopal transfer, despite attempts to limit the practice given its destabilising effect on the Church's leadership. In November I656 Philip IV wrote to the Councils of Castile and Aragón requesting that they 'avoid frequent transfers of prelates from one diocese to another'. ${ }^{27}$ Similar requests had been made under the earlier Philips, demonstrating the continuity of the practice. ${ }^{28}$ Forty-five per cent of nominations to Castilian bishoprics under Philip IV were generated by promotions and 52 per cent by deaths in office. On average six sees were changing hands each year, as opposed to four under the earlier Philips. At the same time there is evidence of a greater incidence of refusals of office occurring on the part of those candidates with the best credentials, giving rise to a 'recruitment crisis' which became particularly acute during the i66os. Nine Castilian bishops refused to take up promotional positions in 1663 alone. A total of twenty-one refusals were recorded in the nine-year period between I66I and I670, which coincided with the change of monarch and the deepening economic crisis. ${ }^{29}$ The wealthier sees with the heaviest financial obligations were those that became increasingly difficult to fill in the later years of Philip IV's reign. Serving bishops (including some members of the orders) preferred to stay put rather than move up the episcopal career ladder and increase their fiscal and pastoral burdens. The archiepiscopal see of Seville (with an annual income of around I00,00o ducats in the I650s) proved to be a particularly undesirable prize. The crown's right to exact between one third and one quarter of the gross value of the most lucrative episcopal

${ }^{27}$ Domínguez Ortiz, Las clases privilegiadas, 227-8.

28 AHN, consejos, legajo I5I93 (consulta for diocese of León, I593: Philip asked for serving bishops not to be put forward as candidates).

29 Ibid. legajos I5256-93 (consultas for I66I-I700). 
Table 5. Average length of tenure of religious orders in Castilian sees, ${ }_{1} 62{ }_{2}-65$ (in years)

\begin{tabular}{|c|c|c|c|c|c|c|c|}
\hline \multicolumn{2}{|c|}{ I see (I7 bishops) } & \multicolumn{2}{|c|}{2 sees (I 4 bishops) } & \multicolumn{2}{|c|}{3 sees (8 bishops) } & \multicolumn{2}{|c|}{4 sees (2 bishops) } \\
\hline \multirow[t]{4}{*}{ First } & 8 & First & $5 \cdot 7$ & First & 2.8 & First & 6.5 \\
\hline & & Second & 5 & Second & 7.6 & Second & 3 \\
\hline & & & & Third & 5.6 & Third & 3 \\
\hline & & $(5 \cdot 3)$ & & $(5 \cdot 3)$ & & $\begin{array}{l}\text { Fourth } \\
(3.8)\end{array}$ & 3 \\
\hline
\end{tabular}

incomes to offer as pensions to long-serving churchmen hit richer sees such as Seville particularly hard. In practice it was liable to concede more than the theoretical maximum of up to 30,000 ducats in pensions, as well as meeting the ordinary and extraordinary taxation demands made upon it of at least Io,ooo ducats. ${ }^{30}$ Enrique Pimentel, bishop of Cuenca (I623-53), declined promotion to Seville in I643 on account of his advanced age and the costs that would be incurred. ${ }^{31}$ Pedro de Urbina OsF was reluctant to accept the see in I658, having already refused a transfer from Valencia to Plasencia in 1655 for financial reasons. ${ }^{32}$ When Seville became vacant again in 1663 , two senior bishops (Jaen and Pamplona) turned it down. ${ }^{33}$ As a result, the crown had to be content with its third choice of candidate, the archbishop of Burgos. The increase in the number of promotional opportunities that arose, combined with a lack of suitable or willing candidates to fill certain vacancies, meant that Philip IV had to draw further upon the potential candidature at his disposal. This situation helped to provide opportunities for new men to enter the profession, a significant proportion of whom were drawn from the religious orders. From the biographical evidence available, it seems that members of the regular clergy tended to be older than their secular counterparts upon taking up office. Their average age on appointment was sixty-one and average age upon death seventy-four. The comparable figures for all bishops appointed under Philip IV are fifty-four and sixty-five respectively. Although they could potentially bring greater stability to the office of bishop on account of their longevity, in practice their periods of tenure tended to be around 5.5 years in length (half the average) as they became engaged in the cycle of frequent transfers from one see to another which characterised the reign: fourteen served in two bishoprics, eight in three and two in four.

30 Antonio Domínguez Ortiz, 'Las rentas del los prelados de Castilla en el siglo XVII', in Estudios de historia económica y social de España, Madrid i987, 223-6o.

${ }^{31}$ M. Barrio Gozalo, 'Perfil socio-económico de una élite de poder, V: Los obispos de Andalucía (I600-1840)', Anthológica Annua xxxiv (1987), 83 .

32 Avisos de Don féronimo de Barrionuevo $\left(I_{65}-I 65^{\circ}\right)$, ccxxi, Madrid I968, entry for 30 Oct I655; ccxxii, Madrid i969, entries for 3i Oct., 7 Nov i657.

${ }^{33}$ AHN consejos, legajo I5257 (consulta for Seville, 22 Feb i663). 
The increased presence of the orders within the Castilian Church significantly reduced that of bishops with university degrees in law from 35 per cent under Philip III to 20 per cent under Philip IV. Correspondingly the percentage of bishops who had a background of experience in state office (predominantly but not exclusively lawyers) fell over the two reigns from 44 per cent to 33 pe rcent. $^{34}$ Given the growing disaffection between Olivares and his senior secular servants (some of whom were also bishops) over policy decisions, it is possible that bishop-theologians were deemed to be more compliant servants and contributors than bishop-jurists, although in practice this did not always prove to be the case. ${ }^{35}$ The decline of the ecclesiastical statesman in office was also an acknowledgement of a general decline in Church-State relations.

In the mid-I65os the Dominican friar Pedro de Tapia emerged as a major agitator for fiscal disobedience amongst the Castilian clergy. As archbishop of Seville from ${ }^{6} 65_{2}$ to ${ }^{6} 657$ (the fourth high-ranking Castilian see in succession he had held since his nomination to Segovia in I64I) he fiercely objected to the renewal of the millones tax - a universal subsidy levied on essential food items - being imposed on the ecclesiastical estate by the crown without the required papal sanction having been received. Tapia led an ecclesiastical revolt, inciting the bishops of Segovia (Francisco de Araujo), Osma (Juan de Palafox) and Málaga (Diego Martínez de Zarzosa) into opposition. ${ }^{36}$ The primate, Baltasar de Moscoso y Sandoval, added his voice of protest to the assault on clerical immunity, threatening to resign over the matter. Allegations of fiscal fraudulence were hurled at the Church by government ministers, invoking a heated response from Friar Araujo of Segovia (a fellow Dominican). He rigorously defended the position of the clergy, whom he claimed were only just able to survive on their incomes and attributed the poor state of royal finances to government maladministration. Friar Araujo's resignation from office in October ${ }_{1} 656$ stands as testimony to his exasperation over the matter. Tapia threatened to take the case to Rome rather than agree to churchmen becoming taxpayers. The Council of Castile discussed removing him from office. In December ${ }_{1} 656$ the newly elected pope, Alexander VII, conceded a renewal of the standard subsidio and excusado subsidies paid by the clergy, but in July of the following year he was still refusing to sanction the renewed levying of the millones tax on the members of the Church. Tapia's death in August I657 must have helped diffuse some of the tension. Within a year Rome had retreated from its position and issued the required sanction. The incident reveals how, under pressure, the crown's most trusted allies could become its fiercest enemies.

${ }^{34}$ Rawlings, 'Castilian episcopal office', table 5 at pp. $62-3$.

35 Ibid. $74^{-7}$.

${ }_{36}$ Avisos de Barrionuevo, ccxxi, entries for 23 Aug., 29 Nov i654; ccxxii, entries for I I Oct., I3, 20 Dec i656, 25 July i657. 
Although during the course of the reign of Philip IV the Dominicans were losing out to the Franciscans over the doctrine of the Immaculate Conception and to the Jesuits in the competition for both university chairs and inquisitorial posts, they nevertheless continued to be major contenders for the highest ranking Castilian episcopal sees, despite their reluctance in some instances to accept the burdens of office. Indeed they increased their hold on high status sees from five in the period I62 I-43 to nine in the period I644-65, remaining the most successful order next to the Franciscans in taking up bishoprics in Castile during the Habsburg period as a whole. The rise of bishops of the habit in mid-seventeenth century Castile may have derived from the tensions that characterised Church-State relations under Philip IV. The demands, both fiscal and political, being placed on senior churchmen to support state expenditure prompted resistance on the part of a significant number of candidates to accept the challenges that being a bishop entailed. The 'crisis of leadership' within the church hierarchy that ensued raised the profile of the religious orders in the competition for preferment. The success of the orders, and in particular that of the Dominicans, served as confirmation of both the conservative and the dogmatic direction of the Spanish Church in the closing decades of Habsburg rule. 


\section{APPENDIX}

Members of religious orders appointed to serve in Castilian bishoprics under Philip IV

\begin{tabular}{|c|c|c|}
\hline Name and order & Background & Episcopal career \\
\hline $\begin{array}{l}\text { Agustín ANTOLÍNEZ } \\
\text { OSA (I554-I626) }\end{array}$ & $\begin{array}{l}\text { Prof. Valladolid, I592-4 } \\
\text { Prof. Salamanca, I594-I609 } \\
\text { Provincial osa Castile, I598 } \\
\text { Junta de IMC, I6I7 }\end{array}$ & $\begin{array}{l}\text { Ciudad Rodrigo, I623-4 } \\
\text { Santiago, I624-6 }\end{array}$ \\
\hline $\begin{array}{l}\text { Francisco de ARAUJO OSD } \\
(\mathrm{I} 580-\mathrm{I} 664)\end{array}$ & $\begin{array}{l}\text { Prof. Salamanca, I6 } 17 \\
\text { calificador inq, I638 }\end{array}$ & Segovia, $164^{8-}{ }^{6} 6$ \\
\hline $\begin{array}{l}\text { Juan de ARAUJO osf } \\
\left(\mathrm{I} 555^{-\mathrm{I} 635)}\right.\end{array}$ & Royal preacher & Guadix, I624-35 \\
\hline $\begin{array}{l}\text { Íñigo de BRIZUELA OSD } \\
\text { (I557-1629) }\end{array}$ & $\begin{array}{l}\text { Royal confessor (Archduke } \\
\text { Albert), I596-I62I } \\
\text { Pres Council Flanders, I623 }\end{array}$ & $\begin{array}{r}\text { Segovia, I622-4 } \\
\text { (renounces see) }\end{array}$ \\
\hline $\begin{array}{l}\text { Domingo CANO de HARO } \\
\text { OSD (d. I639) }\end{array}$ & calificador inq, I626 & Cádiz, ı633-9 \\
\hline $\begin{array}{l}\text { Joseph de la CERDA osB } \\
\text { (d. I644) }\end{array}$ & & $\begin{array}{l}\text { Almería, } 1637-40 \\
\text { Badajoz, } 1640-4\end{array}$ \\
\hline $\begin{array}{l}\text { Alfonso ENRÍQUEZ de } \\
\text { SANTO TOMAS } \\
\text { OSD (I63I / 32-9I) } \\
\text { Antonio ENRÍQUEZ de } \\
\text { TORRES OSF (d. I648) }\end{array}$ & $\begin{array}{l}\text { Bastard son Philip IV } \\
\text { Provincial OSD Andalusia }\end{array}$ & $\begin{array}{l}\text { Osma, I66I-4 } \\
\text { Plasencia, I664 } \\
\text { Málaga, г664-9 } \\
\text { Málaga, г633-48 }\end{array}$ \\
\hline $\begin{array}{l}\text { Francisco GAMBOA } \\
\text { OSA (d. I674) }\end{array}$ & $\begin{array}{l}\text { Prof. Salamanca, I639-55 } \\
\text { Royal confessor (Juan } \\
\text { de Austria) + preacher } \\
\text { calificador inq, I650 } \\
\text { Junta de IMC, I652 }\end{array}$ & $\begin{array}{l}\text { Coria, I659-63 } \\
\text { Zaragoza, I663-74 }\end{array}$ \\
\hline $\begin{array}{l}\text { Pedro de GODOY } \\
\text { OsD (I608-77) }\end{array}$ & $\begin{array}{l}\text { Prof. Salamanca, I652-64 } \\
\text { Royal preacher }\end{array}$ & $\begin{array}{l}\text { Osma, I664-72 } \\
\text { Sigüenza, I672-7 } \\
\text { (Charles II) }\end{array}$ \\
\hline $\begin{array}{l}\text { Pedro GONZÁLEZ } \\
\text { DE MENDOZA } \\
\text { OSF }(\mathrm{I} 570 / 7 \mathrm{I}-\mathrm{I} 639)\end{array}$ & $\begin{array}{l}\text { calificador inq, I } 59^{8} \\
\text { Provincial OSF Castile }\end{array}$ & $\begin{array}{l}\text { Granada, І6 } 6 \text { Іо-І6 } \\
\text { (Philip III) } \\
\text { Zarazoga, І6І6-23 } \\
\text { (Philip III) } \\
\text { Sigüenza, І623-39 }\end{array}$ \\
\hline $\begin{array}{l}\text { José GONZÁLEZ } \\
\text { DE VILLALOBOS Y } \\
\text { DÍAZ OSD ( } 1566-163 \mathrm{I})\end{array}$ & $\begin{array}{l}\text { calificador inq, I6I2 } \\
\text { Royal preacher } \\
\text { Provincial OSD Spain, I6 I I } \\
\text { Confessor (Prince Felipe) }\end{array}$ & $\begin{array}{l}\text { Palencia, I6I6-25 (Philip III) } \\
\text { Pamplona, I625-7 } \\
\text { Santiago, I627-30 } \\
\text { Burgos, I630-1 }\end{array}$ \\
\hline $\begin{array}{l}\text { Francisco GUERRA, } \\
\text { OSF (d. I658) }\end{array}$ & $\begin{array}{l}\text { calificador inq, I6 } 632 \\
\text { Junta IMC, I657 }\end{array}$ & $\begin{array}{l}\text { Cádiz, I642-56 } \\
\text { Plasencia, I656-8 }\end{array}$ \\
\hline $\begin{array}{l}\text { Juan de GUZMÁN } \\
\text { OsF (??) }\end{array}$ & & $\begin{array}{l}\text { Canarias, } \mathrm{I} 622-7 \\
\text { Tarragona, } 1627-38\end{array}$ \\
\hline
\end{tabular}


Appendix. (Cont.)

\begin{tabular}{|c|c|c|}
\hline Name and order & Background & Episcopal career \\
\hline $\begin{array}{l}\text { Pedro Diego HERRERA } \\
\text { OSD (I548-I63o) }\end{array}$ & $\begin{array}{l}\text { Prof. Theology Salamanca, } \\
\text { I593-162 I }\end{array}$ & $\begin{array}{l}\text { Canarias, I62 I-2 (Philip III) } \\
\text { Tuy, I622-30 } \\
\text { Tarazona, I630-I }\end{array}$ \\
\hline $\begin{array}{l}\text { Joseph LAÍNEZ } \\
\text { OSA (d. I667) }\end{array}$ & Royal preacher, I635 & Guadix, I653-67 \\
\hline $\begin{array}{l}\text { Martín LÓPEZ DE } \\
\text { ONTIVEROS } \\
\text { OSB (d. ı666) }\end{array}$ & & $\begin{array}{l}\text { Calahorra, I657-8 } \\
\text { Valencia, I658-66 }\end{array}$ \\
\hline $\begin{array}{l}\text { Nicolás de MADRID } \\
\text { OsJ (1600-6o) }\end{array}$ & Prior San Lorenzo, I648-54 & $\begin{array}{l}\text { Astorga, I654-6o } \\
\text { Osma, I66o }\end{array}$ \\
\hline $\begin{array}{l}\text { Angel MANRIQUE } \\
\text { ocist (I } 577-\text { I649) }\end{array}$ & $\begin{array}{l}\text { General ocist, I626-9 } \\
\text { Prof. Salamanca, I6I5-38 } \\
\text { Junta IMC, I643 }\end{array}$ & Badajoz, I645-9 \\
\hline $\begin{array}{l}\text { Juan MERINO } \\
\text { OSF }\left(15^{8} 3^{-1663)}\right.\end{array}$ & General, order & Valladolid, I647-63 \\
\hline $\begin{array}{l}\text { Bernardo de ONTIVEROS } \\
\text { OsB (d. I662) }\end{array}$ & $\begin{array}{l}\text { General, order } \\
\text { Junta IMC, I658 }\end{array}$ & Calahorra, I659-62 \\
\hline $\begin{array}{l}\text { Plácido PACHECO de } \\
\text { HARO osB (d. I639) }\end{array}$ & General, order, I62I & $\begin{array}{l}\text { Cádiz, I623-33 } \\
\text { Plasencia, I633-9 }\end{array}$ \\
\hline $\begin{array}{l}\text { Gregorio de PEDROSA } \\
\text { OSJ }(\mathrm{I} 57 \mathrm{I}-\mathrm{I} 646)\end{array}$ & $\begin{array}{l}\text { Prof. Salamanca } \\
\text { calificador inq, I6o8 } \\
\text { Royal preacher, I6o9 } \\
\text { General, order, I624 }\end{array}$ & $\begin{array}{l}\text { León, I624-33 } \\
\text { Valladolid, I633-45 }\end{array}$ \\
\hline $\begin{array}{l}\text { Juan de PERALTA } \\
\text { OSJ (d. I629) }\end{array}$ & Prior San Lorenzo, I6I2-2I & $\begin{array}{l}\text { Tuy, I62 I-2 } \\
\text { Zamora, I622-4 } \\
\text { Zaragoza, I624-9 }\end{array}$ \\
\hline $\begin{array}{l}\text { Alfonso PÉREZ HUMANES } \\
\text { Ocist (d. I663) }\end{array}$ & $\begin{array}{l}\text { General ocist, }{ }^{16} 5^{-}-3 \\
\text { Junta IMC, I } 65^{8}\end{array}$ & $\begin{array}{l}\text { Almería, I659-63 } \\
\text { Cádiz, ı } 663\end{array}$ \\
\hline $\begin{array}{l}\text { Domingo PIMENTEL } \\
\text { OSD }\left(1585^{-1} 653\right)\end{array}$ & $\begin{array}{l}\text { Prof. Valladolid, I6 } 618+\text { I6 } 624 \\
\text { Provincial OSD, I619-23 } \\
\text { Ambassador Rome, I633-7 }\end{array}$ & $\begin{array}{l}\text { Osma, I6 } 63^{-}-3 \\
\text { Córdoba, I633-49 } \\
\text { Sevilla, I649-52 } \\
\text { (renounces see) }\end{array}$ \\
\hline $\begin{array}{l}\text { Juan del POZO } \\
\text { OSD }\left(5^{8} 4^{-1660}\right)\end{array}$ & $\begin{array}{l}\text { Royal preacher } \\
\text { calificador inq, I638 }\end{array}$ & $\begin{array}{l}\text { Lugo, I646-5o } \\
\text { León, I650-6 } \\
\text { Segovia, I656-6o }\end{array}$ \\
\hline $\begin{array}{l}\text { Bernardo RODRÍGUEZ } \\
\text { de ARRIAGA } \\
\text { OSA (d. I65I) }\end{array}$ & $\begin{array}{l}\text { Prof. Salamanca, I6o8-37 } \\
\text { Provincial osA, Andalusia, } \\
\text { I627+ I64I }\end{array}$ & Guadix, I648-5I \\
\hline $\begin{array}{l}\text { Jerónimo RODRÍGUEZ } \\
\text { VALDERAS } \\
\text { OMerc (I592-167I) }\end{array}$ & Provincial omerc & $\begin{array}{l}\text { Badajoz, I662-8 } \\
\text { Jaén, I668-7I } \\
\text { (Charles II })\end{array}$ \\
\hline $\begin{array}{l}\text { Alfonso de SAN } \\
\text { VITORES OsB (d. I659) }\end{array}$ & $\begin{array}{l}\text { calificador inq, I626 } \\
\text { Royal preacher } \\
\text { General, order, } 1633-7\end{array}$ & $\begin{array}{l}\text { Almería, I651-3 } \\
\text { Orense, I653-9 } \\
\text { Zamora, I659 }\end{array}$ \\
\hline
\end{tabular}


Appendix. (Cont.)

\begin{tabular}{|c|c|c|}
\hline Name and order & Background & Episcopal career \\
\hline $\begin{array}{l}\text { Juan de la SERNA } \\
\text { OsJ (1568-1646) }\end{array}$ & Prior San Lorenzo & Lugo, I643-6 \\
\hline $\begin{array}{l}\text { Diego SERRANO, } \\
\text { OMerc }\left(15^{8}-165^{2}\right)\end{array}$ & $\begin{array}{l}\text { Provincial omerc } \\
\text { Andalusia, I631 } \\
\text { General, order, I632 } \\
\text { calificador inq, I633 }\end{array}$ & $\begin{array}{l}\text { Solsona, I6 } 635^{-9} \\
\text { Segorbe, I639-52 } \\
\text { Guadix, I } 65^{2}\end{array}$ \\
\hline $\begin{array}{l}\text { Pedro de TAPIA } \\
\text { OsD (I582-I657) }\end{array}$ & $\begin{array}{l}\text { calificador inq, I624 } \\
\text { Prof. Alcalá, I623 }\end{array}$ & $\begin{array}{l}\text { Segovia, I64I-5 } \\
\text { Sigüenza, I645-9 } \\
\text { Córdoba, I6 } 649^{-5} 5^{2} \\
\text { Seville, I652-7 }\end{array}$ \\
\hline $\begin{array}{l}\text { Juan de TOLEDO } \\
\text { OSJ (I6oI-72) }\end{array}$ & $\begin{array}{l}\text { Royal preacher } \\
\text { calificador inq, I6oo }\end{array}$ & $\begin{array}{l}\text { Canarias, I659-65 } \\
\text { León, I } 665-72\end{array}$ \\
\hline $\begin{array}{l}\text { Plácido de TOSANTOS } \\
\text { OsB (d. I624) }\end{array}$ & $\begin{array}{l}\text { General, order OSB } \\
\text { Royal preacher } \\
\text { Junta IMC, I6I } 6\end{array}$ & $\begin{array}{l}\text { Guadix, I620-4 } \\
\text { (Philip III) } \\
\text { Zamora, I624 }\end{array}$ \\
\hline $\begin{array}{l}\text { Francisco de TORRES } \\
\text { Y GRIJALVA } \\
\text { OSD (d. I662) }\end{array}$ & Prior Roncevalles & Mondoñedo, I648-62 \\
\hline $\begin{array}{l}\text { Pedro de URBINA } \\
\text { OsF (I585-1663) }\end{array}$ & $\begin{array}{l}\text { calificador inq, I629 } \\
\text { Provincial OSF, } \\
\text { Castile Junta IMC, I643 }\end{array}$ & $\begin{array}{l}\text { Coria, I644-9 } \\
\text { Valencia, I649-58 } \\
\text { Seville, ı6 } 65^{8-63}\end{array}$ \\
\hline $\begin{array}{l}\text { Alfonso VÁZQUEZ } \\
\text { DE TOLEDO, } \\
\text { OsF (d. 1672) }\end{array}$ & calificador inq, I66o & Cádiz, I663-72 \\
\hline $\begin{array}{l}\text { Juan VENIDO } \\
\text { OSF (I555?-I63I) }\end{array}$ & Royal confessor (Infantes) & Orense, $1626-3$ I \\
\hline $\begin{array}{l}\text { Antonio VIEDMAY } \\
\text { CHAVES osd (d. I63I) }\end{array}$ & & Almería, I630-I \\
\hline $\begin{array}{l}\text { Juan de VILLAMAR } \\
\text { OsF (d. I666) }\end{array}$ & Comisario General osf, I659 & Tuy, г659-66 \\
\hline
\end{tabular}

